\title{
Sclerotia morphology traits and mycelial growth rate are not informative variables for population studies of Sclerotinia sclerotiorum
}

\author{
Miller S. Lehner ${ }^{1}$, Trazilbo J. Paula Júnior ${ }^{2}$, Rhaphael A. Silva ${ }^{3}$, Rogério F. Vieira ${ }^{2}$, José Eustáquio S. \\ Carneiro $^{4}$ \& Eduardo S. G. Mizubuti ${ }^{5}$
}

'Programa de Pós-graduação em Genética e Melhoramento, Universidade Federal de Viçosa, 36570-000, Viçosa, MG, Brazil; ${ }^{2}$ EPAMIG, Vila Gianetti 47, 36570-000, Viçosa, MG, Brazil; ${ }^{3}$ Universidade Federal de Viçosa, 36570-000, Viçosa, MG, Brazil; ${ }^{4}$ Departamento de Fitotecnia, Universidade Federal de Viçosa, 36570-000, Viçosa, MG, Brazil; ${ }^{5}$ Departamento de Fitopatologia, Universidade Federal de Viçosa, 36570-000, Viçosa, MG, Brazil

Author for correspondence: Eduardo S. G. Mizubuti, e-mail: mizubuti@ufv.br

\begin{abstract}
The usefulness of sclerotia morphology traits and mycelial growth rate to infer phenotypic variability in populations of Sclerotinia sclerotiorum associated with common beans in Minas Gerais State (MG) was assessed in two experiments. Isolates (131) were collected in the Northwestern, Alto Paranaíba, Zona da Mata and Southern regions of MG and the mycelial growth rate, the number, weight and dimensions (length, width and thickness) of sclerotia and mycelial pigmentation were assessed. There was a high variability among isolates, even among colonies of the same isolate. The variance of the first experiment for the mycelial growth rate, number, weight, length, width and thickness of sclerotia, were $0.01,190.15,0.01,0.62,0.12$ and 0.05 , whereas in the second, the variances were $0.01,28.48$, $0.002,0.18,0.06$ and 0.03 , respectively. Most correlations between traits were of low magnitude except that between length and width $(\mathrm{r}=0.84, \mathrm{P}<0.001)$. Regarding colony pigmentation, non-pigmented, pigmented and highly pigmented isolates were identified, but for most isolates this characteristic varied between experiments. No groups based on phenotypic traits were detected. The morphological traits evaluated in the present study are not suitable for characterization of populations of S. sclerotiorum.
\end{abstract}

Key words: Phaseolus vulgaris, sclerotium, phenotypic variability, white mold.

Several biological features make the ascomycete Sclerotinia sclerotiorum (Lib.) de Bary a highly threatening fungal pathogen to important crops in Brazil. Sclerotinia sclerotiorum is a homothallic fungus that does not produce conidia, but abundant sclerotia (Bolton et al., 2006). Sclerotia are asexual resting structures that allow pathogen survival when no host is available (Adams \& Ayers, 1979). The pathogen has a host range that encompasses over 400 plant species (Boland \& Hall 1994). Furthermore, pathogen propagules (sclerotia) can be easily spread over long-distance by contaminated seeds. Sclerotinia sclerotiorum causes white mold in crops such as cotton, soybean, potato, sunflower etc., and is the main soilborne disease affecting common bean (Phaseolus vulgaris L.) in Minas Gerais State (MG), Brazil.

In Brazil common bean is produced in the springsummer, summer-fall, and fall-winter growing seasons (Vieira et al., 2010). Considering the three growing seasons, MG is the second largest producer, but ranks first during the fall-winter, with an average yield of $2600 \mathrm{~kg} \mathrm{ha}^{-1}$ (CONAB, 2013). In the fall-winter growing season, moderate temperatures and high humidity provided by irrigation create conducive environmental conditions for white mold epidemics (Paula Júnior et al., 2006).
Planting white mold resistant cultivar would be attractive alternative for disease management. Nevertheless, to date there are no resistant varieties available to growers. Sound breeding programs require proper understanding of the pathogen variability. The variability of populations of $S$. sclerotiorum has been investigated for different crops around the world and most studies have focused on polymorphisms of neutral molecular markers (Cubeta et al., 1997; Sexton et al., 2004; Sexton et al., 2006; Malvárez et al., 2007; Ekins et al., 2011; Gomes et al., 2011; Clarkson et al., 2013).

Phenotypic variability has been observed among isolates of S. sclerotiorum collected from different hosts in Canada (Morral et al., 1972), rape in Turkey (Merk-Turk et al., 2007) and Australia (Garg et al., 2010) and canola in China and USA (Attanayake et al., 2013). On the other hand, phenotypic uniformity was observed among isolates from potato in USA (Atallah et al., 2004). Despite the relevance of white mold epidemics to the Brazilian agriculture, no study has been conducted to assess phenotypic variability of Brazilian isolates of S. sclerotiorum and none is available for population of the pathogen attacking common bean. Moreover, there is very limited published information on the variation in sclerotia morphology, even though it 
is a taxonomic characteristic used in the classification of Sclerotinia spp. (Willets, 1980).

The aim of this study was to assess the morphological variability among isolates of $S$. sclerotiorum collected from different common bean areas in four regions of MG, Brazil. The main question asked is: are phenotypic traits informative variables for assessing variation in populations of $S$. sclerotiorum?

Isolates of $S$. sclerotiorum were obtained after sampling sclerotia in common bean fields located in the Northwestern (16 fields), Alto Paranaíba (5 fields), Zona da Mata (14 fields) and Southern (2 fields) regions of MG. These areas account for approximately $76 \%$ of the total common bean produced in the State (IBGE, 2013). In each area one to 12 isolates were collected depending on the disease incidence and field size. The distance among sampled plants was at least $10 \mathrm{~m}$.

In the Northwestern region of MG, sclerotia were collected in August 2010, in center pivot irrigated areas planted with the cultivar Pérola. In the Zona da Mata region samples were collected in June 2010 in non-irrigated areas, planted with the cultivar Ouro Vermelho. In the Alto Paranaíba region, sclerotia were collected in center pivot areas planted with the cultivar Pérola in October 2010 (Patos de Minas) and January 2011 (Iraí de Minas). Sclerotia originating from the Southern region were from: Ijaci (collected in a center pivot irrigated area in October 2009, planted to cultivar Talismã) and Lambari (collected in May 2010 in a non-irrigated area, planted with an unspecified cultivar of the Carioca group).

One sclerotium from each sampled bean plant was surface disinfested for $1 \mathrm{~min}$ in 70\% ethanol, followed by 3 min in $1 \%$ sodium hypochlorite. Sclerotia were rinsed twice in distilled water and transferred to $9 \mathrm{~cm}$ diameter-Petri dishes containing $20 \mathrm{~mL}$ of PDA (potato, dextrose, agar, Acumedia Manufacturers, Inc.) medium amended with chloramphenicol $\left(100 \mathrm{mg} \mathrm{L}^{-1}\right)$. Plates were maintained at $23^{\circ} \mathrm{C}$ in the dark. After six days, mycelial tips were transferred to freshly prepared PDA plates, which were maintained at $23^{\circ} \mathrm{C}$ in the dark for $10-15$ days and then kept at $4^{\circ} \mathrm{C}$.

Isolates collected in the same geographic region were considered as belonging to the same population. The number of isolates in the Northwestern, Zona da Mata, Alto Paranaíba and in the Southern regions was 46, 42, 20 and 23 , respectively.

Mycelial plugs (5 $\mathrm{mm}$ diameter) from a 2-day-old culture of the 131 isolates were placed in the center of Petri dishes ( $9 \mathrm{~cm}$ diameter) containing $15 \mathrm{~mL}$ of PDA amended with $100 \mathrm{mg} \mathrm{L}^{-1}$ of chloramphenicol, $\mathrm{pH}$ 5.6, and incubated at $23^{\circ} \mathrm{C}$ in the darkness. Colony diameter was assessed twice: after 12 and $18 \mathrm{~h}$. The average growth rate $\left(\mathrm{mm} \mathrm{h}^{-1}\right)$ was estimated as: (diameter after $18 \mathrm{~h}$ - diameter after 12 h) $/ 6$. After 25 days of incubation, the mycelial pigmentation of colonies was visually evaluated and recorded as nonpigmented, pigmented and highly pigmented. Ten sclerotia per plate were arbitrarily chosen for evaluation of length, width and thickness, using a digital caliper. Sclerotia were also counted and weighed. The experiment was performed twice. Experiments were set in a completely randomized design with three (Experiment 1) or four (Experiment 2) replicates. A colony growing in a plate was considered as an experimental unit.

Variance of all continuous variables was estimated for each isolate as well as the coefficient of coincidence or simple matching (Sokal \& Michener, 1958) for mycelial pigmentation of colonies in each experiment. Data from two experiments were pooled for principal components (PCA), principal coordinates (PCoA), Fisher discriminant and correlation analyses. The relationship between isolates and assessed traits was examined by a biplot graphical representation for PCA. PCA and Pearson's correlation coefficients were performed using the $\mathrm{R}$ program ( $\mathrm{R}$ Development Core Team). Since the data were of different scales, the correlation matrix was chosen to correctly interpret the results. The relationship between isolates and traits was displayed using a point-vector plot, with points representing isolates and directional vectors representing traits. Grouping of the isolates was also carried out by PCoA using GenAlEx. The PCoA was conducted on the Mahalanobis distance among all isolates which was calculated using GENES software (Cruz, 2006) as well as the Fisher discriminant analysis.

In the first experiment, the average mycelial growth rate varied from $1.26 \mathrm{~mm} \mathrm{~h}^{-1}$ (std. dev. $=0.05$ ) to $2.22 \mathrm{~mm}$ $\mathrm{h}^{-1}( \pm 0.03)$ and the overall mean was $1.72 \mathrm{~mm} \mathrm{~h}^{-1}$. The average number of sclerotia per plate varied from $12( \pm 10)$ to $72( \pm 8)$ and the overall mean was 39 . The range of the average values of fresh weight, length, width, and thickness of sclerotia were $0.13 \mathrm{~g}( \pm 0.06 \mathrm{~g})$ to $0.83 \mathrm{~g}( \pm 0.11) ; 2.38$ $\mathrm{mm}( \pm 0.05)$ to $6.45 \mathrm{~mm}( \pm 0.24) ; 1.70 \mathrm{~mm}( \pm 0.05)$ to 3.57 $\mathrm{mm}( \pm 0.02)$; and $1.09 \mathrm{~mm}( \pm 0.14)$ to $2.14 \mathrm{~mm}( \pm 0.23)$; with mean values of $0.43 \mathrm{~g}, 3.79 \mathrm{~mm} ; 2.40 \mathrm{~mm}$; and 1.55 , respectively.

In the second experiment, the average mycelial growth rate varied from $1.42 \mathrm{~mm} \mathrm{~h}^{-1}( \pm 0.03)$ to $2.37 \mathrm{~mm} \mathrm{~h}^{-1}$ $( \pm 0.09)$ and the overall mean was $1.88 \mathrm{~mm} \mathrm{~h}^{-1}$. The average number of sclerotia (39) produced by isolates in Experiment 1 was higher than in Experiment 2 (21). The average fresh weight varied from $0.03 \mathrm{~g}( \pm 0.02)$ to $0.29 \mathrm{~g}( \pm 0.07)$ and the overall mean was $0.14 \mathrm{~g}$. The average values of length, width and thickness were similar in both experiments. In the second experiment the average values of these variables ranged from $1.84 \mathrm{~mm}( \pm 0.21)$ to $4.06 \mathrm{~mm}( \pm 0.48)$; from $1.37 \mathrm{~mm}( \pm 0.55)$ to $2.82 \mathrm{~mm}( \pm 0.13)$; and from $1.00 \mathrm{~mm}$ $( \pm 0.13)$ to $1.92 \mathrm{~mm}( \pm 0.19)$. The overall mean values were $2.97 \mathrm{~mm}, 2.10 \mathrm{~mm}$ and $1.38 \mathrm{~mm}$, respectively.

The variance of mycelial growth rate ranged from zero to 0.11 in experiment 1 and from 0.001 to 0.125 in experiment 2 (Figure 1A). Regarding the number of sclerotia, the estimated variance in the first experiment was higher than in the second. It ranged from zero to 974.3 (experiment 1) and from 0.25 to 116.9 (experiment 2) (Figure 1B). 
Similarly, there was greater variation in length, width and thickness of sclerotia in the first experiment (Figure 1D, 1E and $1 \mathrm{~F}$ ). For fresh weight of sclerotia the variance ranged from zero to 0.11 in experiment 1 and from zero to 0.02 in experiment 2 (Figure 1C).

In experiment 1, 21 isolates were rated as nonpigmented, 32 as pigmented and 11 as highly pigmented. The coefficient of coincidence for colony color of these isolates was $100 \%$. For 67 isolates the mycelial pigmentation varied among colonies. For two of them the color coefficient of coincidence was $33 \%$, and for 65 isolates the coefficient was $66 \%$. In the second experiment the color coefficient of coincidence for 98 isolates was $100 \%$ (2 non-pigmented, 79 pigmented and 17 highly pigmented). For 16 isolates the coefficient was $50 \%$ and for 17 isolates $75 \%$. Only one isolate was not pigmented in both experiments. On the other hand, for 11 isolates rated as highly pigmented in the first experiment, eight had the same classification in the second experiment.

There was a negative correlation between growth rate and sclerotia width $(r=-0.19, P=0.026)$. The other
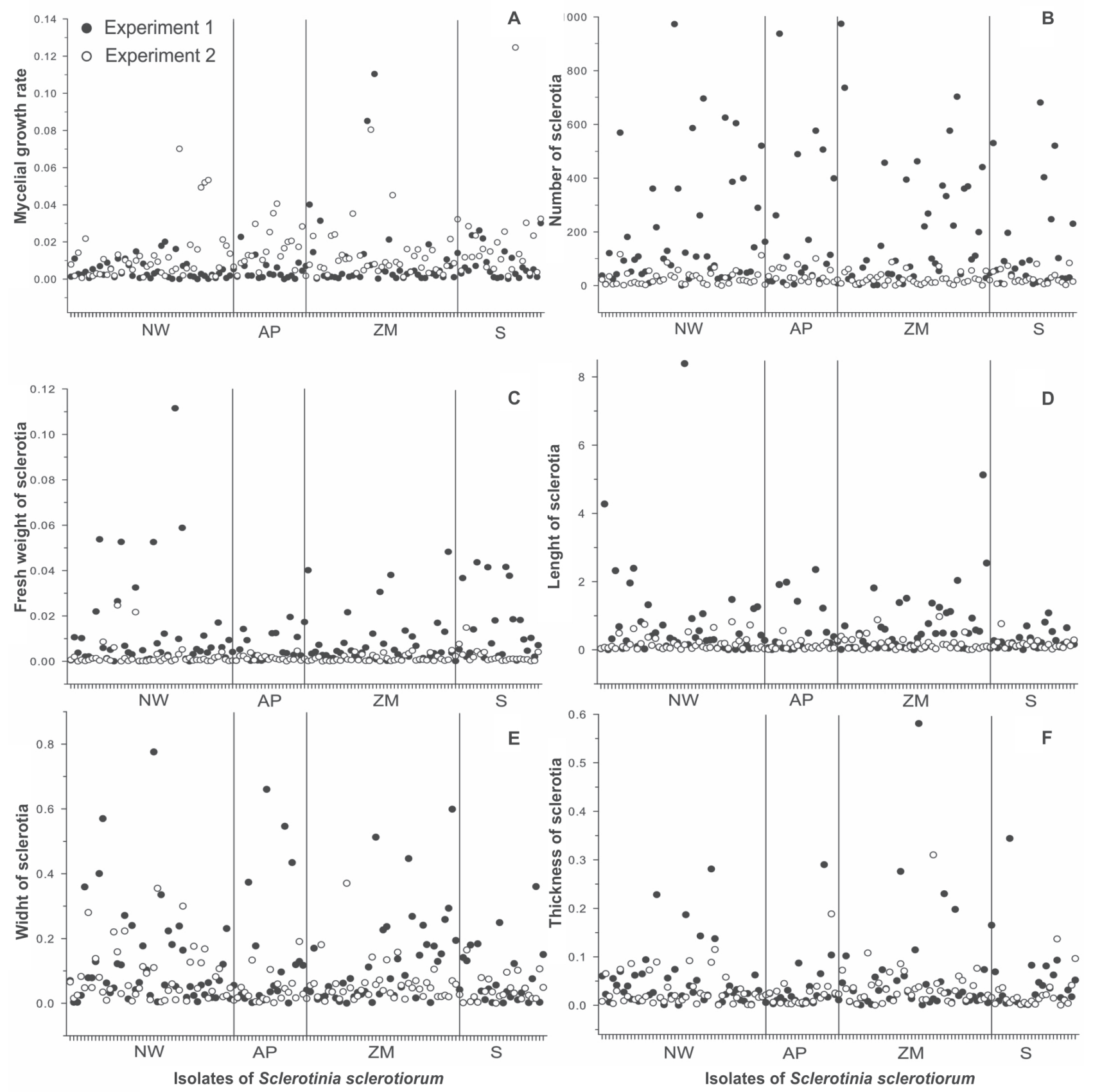

FIGURE 1 - Scatter plot of variances of mycelial growth rate (A), number (B), total fresh weight (C), length (D), width (E) and thickness (F) of sclerotia among isolates of Sclerotinia sclerotiorum. Isolates were collected from the following regions of Minas Gerais, Brazil: Northwestern (NW), Alto Paranaíba (AP), Zona da Mata (ZM) and South (S). 
variables were not correlated to growth rate. Similarly, there was no correlation between fresh weight and sclerotia thickness. There was a low negative correlation between number of sclerotia and length $(r=-0.22, P=$ $0.009)$, width $(r=-0.34, P<0.001)$, and thickness $(r=$ $-0.28, P=0.001)$. There was a low positive correlation between number of sclerotia and fresh weight $(r=0.49$, $P<0.001)$, fresh weight and sclerotia length $(r=0.55$, $P<0.001)$, fresh weight and sclerotia width $(r=0.46$, $P<0.001)$, sclerotia length and thickness $(r=0.34$, $P<0.001)$ and between sclerotia width and thickness $(r=0.47, P<0.001)$. A high positive correlation was estimated between length and width $(r=0.84, P<0.001)$ (Figure 2).
The first two principal components explained $68 \%$ of total variation. Isolates did not group according to geographic region or other criteria (Figure 3). The PCoA based on the Mahalanobis distance explained 59\% of total variation when the first two principal components were accessed. No grouping was detected (data not shown). The Fisher discriminant analysis resulted in 59 wrong classifications (error rate of $45 \%$ ) indicating that populations are not different or that the variables used are not useful to discriminate the putative populations (Cruz et al., 2011).

There is a high morphological variability among $S$. sclerotiorum isolates. Mycelial and sclerotial characteristics can change rapidly making them inadequate markers for population studies. Furthermore, instability in phenotypic

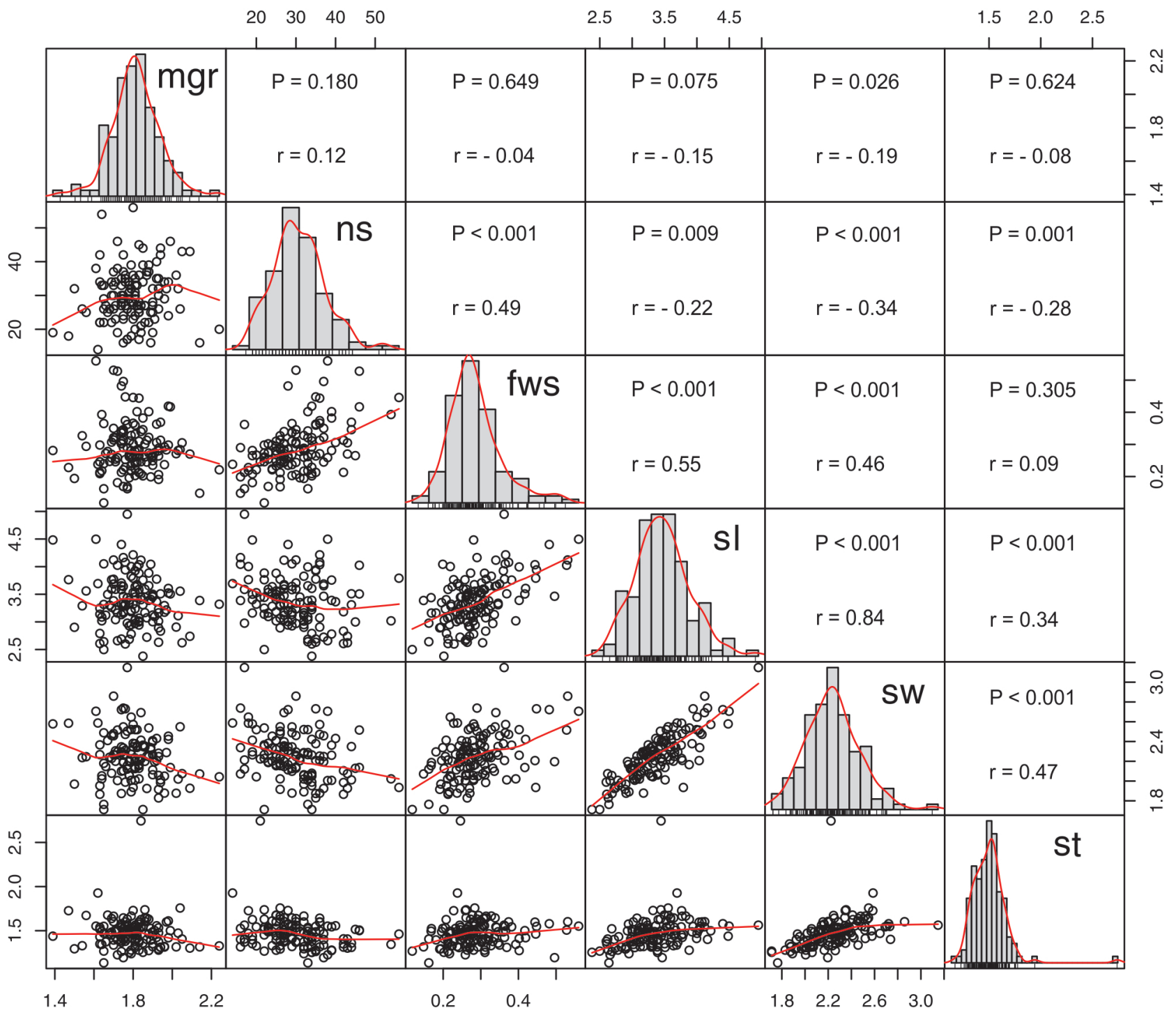

FIGURE 2 - Pearson's correlation coefficient and P values (above the diagonal) and bivariate scatterplots with a fitted line (below the diagonal) between mycelial growth rate (mgr), number (ns), total fresh weight (fws), length (sl), width (sw) and thickness (st) of sclerotia produced by 131 isolates of Sclerotinia sclerotiorum on potato-dextrose-agar. A histogram of each variable is shown in the main diagonal. 
traits was often observed, making comparisons and interpretation of results conducted in different places or at different dates a difficult task. There was no association between phenotypic traits and any feature of interest (geographic location or bean cultivar) when the data were analyzed using different techniques. It is concluded that the phenotypic traits assessed in this study are not reliable markers for investigating populations of S. sclerotiorum.

Although of low magnitude, the significant negative correlation between the number and dimensions of sclerotia indicate that the higher the number of sclerotia produced, the smaller the size. As expected, sclerotia number and dimensions (length and width) were positively correlated with total fresh weight of sclerotia. One unanticipated finding was that long sclerotia also tend to be wider and thicker. Except for a low negative correlation between mycelial growth and sclerotia width, mycelial growth rate was not correlated with any other variable. This result is consistent with previous studies (Li et al., 2008; Vleugels et al., 2013) and suggests that mycelial growth has no influence on the production of sclerotia.

The dark color of $S$. sclerotiorum results from the production of melanin, which protects the fungus from adverse biological and environmental conditions (Henson et al., 1999). In a previous study (Garg et al., 2010) there was no correlation between mycelial pigmentation and aggressiveness of $S$. sclerotiorum but the number of isolates involved was small $(\mathrm{N}=8)$. Intense pigmentation of mycelium has been reported for isolates of $S$. sclerotiorum in Australia (Garg et al., 2010), USA (Sanogo \& Puppala, 2007; Attanayake et al., 2012) and China (Attanayake et al., 2013). Within the group of pigmented isolates, there is variation in color intensity (Garg et al., 2010). In the current study, although many isolates varied regarding the intensity of pigmentation, at least eight were highly pigmented in all experimental units considering the two experiments. These isolates always developed highly pigmented colonies, regardless of how many times they were subcultured. Apparently, these isolates were genetically stable in the timeframe of this study. Three isolates changed from highly pigmented to pigmented, but non-pigmented isolates never became highly pigmented.

In general, the mycelial growth rate and the dimensions of sclerotia were similar in both experiments. However, the number of sclerotia produced by each isolate differed. In the first experiment 120 isolates produced on average more than 20 sclerotia per plate. In the second experiment only 60 isolates formed these many sclerotia. Not only were the number of sclerotia reduced, but also the variation among experimental units regarding this trait. In general, the variance of the phenotypic traits was greater in the first than in the second experiment.

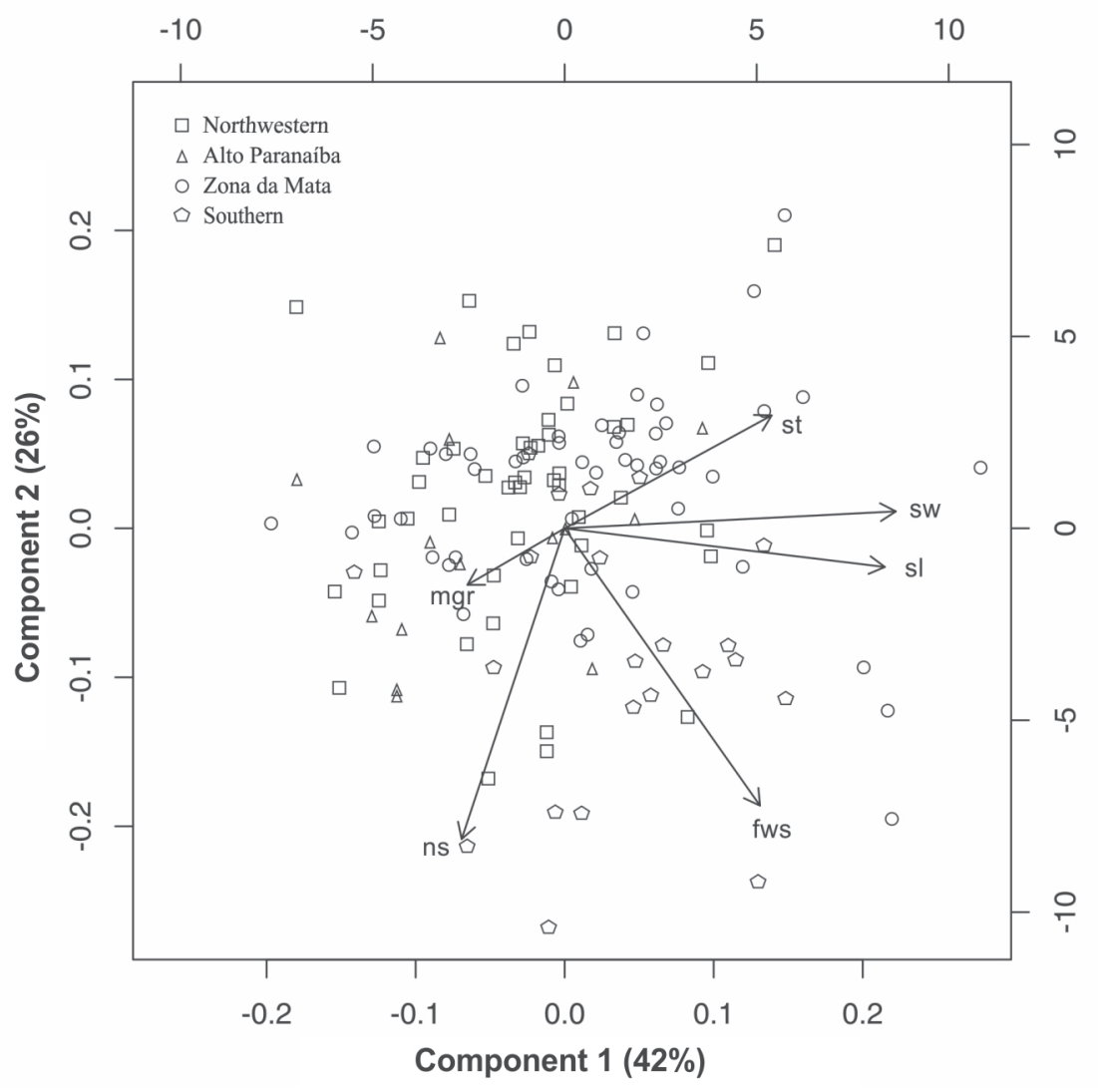

FIGURE 3 - Principal component analysis (PCA) of the phenotypic variation observed for 131 isolates of Sclerotinia sclerotiorum from common bean fields located in four regions of Minas Gerais State, Brazil. Mgr = mycelial growth rate at $23^{\circ} \mathrm{C}$; ns $=$ number of sclerotia per plate; fws $=$ fresh weight of total sclerotia per plate; $\mathrm{sl}=$ length of ten sclerotia per plate; $\mathrm{sw}=$ width of ten sclerotia per plate; $s t=$ thickness of ten sclerotia per plate. 
Experiment 1 was performed in the beginning of 2011, shortly after isolates were obtained. Experiment 2 was performed in 2013. Isolates were stored as sclerotia maintained in paper envelopes at $4^{\circ} \mathrm{C}$ between experiments. Storage temperature could have affected the isolates, but colonies from stored sclerotia were recovered by myceliogenic germination which is not as affected by low temperature as carpogenic germination (Coley-Smith \& Cooke 1971). Therefore, the reasons for the smaller variance in the experiment 2 are difficult to be clearly determined.

Morral et al. (1972) described high phenotypic variability among 114 isolates of Sclerotinia spp. In the present study, the phenotypic traits evaluated were highly variable among isolates of $S$. sclerotiorum and also among colonies of the same isolates, regardless of their origin. For example, in the first experiment, isolate Ss-1 formed 68 sclerotia in one plate and seven sclerotia in another. The study of the mechanisms driving variability of morphological traits still requires further research for proper elucidation.

\section{ACKNOWLEDGEMENTS}

Miller S. Lehner was supported by Coordenação de Aperfeiçoamento de Pessoal de Nível Superior - CAPES. Trazilbo J. Paula Júnior, José Eustáquio S. Carneiro, Rogério F. Vieira and Eduardo S. G. Mizubuti were supported by Conselho Nacional de Desenvolvimento Científico e Tecnológico - CNPq. Rhaphael A. Silva was supported by Fundação de Amparo à Pesquisa do Estado de Minas Gerais - FAPEMIG. This research was supported by FAPEMIG and CNPq.

\section{REFERENCES}

Adams PB, Ayers WA (1979) Ecology of Sclerotinia species. Phytopathology 69:896-99.

Atallah ZK, Larget B, Chen X, Johnson DA (2004) High genetic diversity, phenotypic uniformity, and evidence of outcrossing in Sclerotinia sclerotiorum in the Columbia basin of Washington State. Phytopathology 94:737-742.

Attanayake RN, Porter L, Johnson DA, Chen W (2012) Genetic and phenotypic diversity and random association of DNA markers of isolates of the fungal plant pathogen Sclerotinia sclerotiorum from soil on a fine geographic scale. Soil Biology and Biochemistry 55:28-36.

Attanayake RN, Carter PA, Jiang D, del Río-Mendoza L, Chen W (2013) Sclerotinia sclerotiorum populations infecting canola from China and the United States are genetically and phenotypically distinct. Phytopathology 103:750-761.

Boland GJ, Hall R (1994) Index of plant hosts of Sclerotinia sclerotiorum. Canadian Journal of Plant Pathology 16:93-108.

Bolton MD, Thomma BPHJ, Nelson BD (2006) Sclerotinia sclerotiorum (Lib) de Bary: biology and molecular traits of a cosmopolitan pathogen. Molecular Plant Pathology 7:1-16.

Coley-Smith JR, Cooke RC (1971) Survival and germination of fungal sclerotia. Annual Review of Phytopathology 9: 65-92.
CONAB. Feijão, safra 2012-2013. Available at: www.conab.gov. br. Accessed on March, 2013.

Clarkson JP, Coventry E, Kitchen J, Carter HE, Whipps JM (2013) Population structure of Sclerotinia sclerotiorum in crop and wild hosts in the UK. Plant Pathology 62:309-324.

Cruz CD (2006) Programa Genes: Biometria. Editora UFV. Viçosa (MG).

Cruz CD, Ferreira FM, Pessoni LA (2011) Biometria Aplicada ao Estudo da Diversidade Genética. $1^{\text {st }}$ Ed. Visconde do Rio Branco, MG. Suprema.

Cubeta MA, Cody BR, Kohli Y, Kohn LM (1997) Clonality in Sclerotinia sclerotiorum on infected cabbage in Eastern North Carolina. Phytopathology 87:1000-1004.

Ekins MG, Hayden HL, Aitken EAB, Goulter KG (2011) Population structure of Sclerotinia sclerotiorum on sunflower in Australia. Australasian Plant Pathology 40:99-108.

Garg H, Kohn LM, Andrew M, Li H, Sivasithamparam K, Barbetti MJ (2010) Pathogenicity of morphologically different isolates of Sclerotinia sclerotiorum with Brassica napus and B. juncea genotypes. European Journal of Plant Pathology 126:305-315.

Gomes EV, Nascimento LB, Freitas MA, Nasser LCB, Petrofeza S (2011) Microsatellite markers reveal genetic variation within Sclerotinia sclerotiorum populations in irrigated dry bean crops in Brazil. Journal of Phytopathology 159:94-98.

Henson JM, Butler MJ, Day AW. (1999) The dark side of the mycelium: melanins of phytopathogenic fungi. Annual Review of Phytopathology 37:447-471.

IBGE. Levantamento sistemático da produção agrícola. Rio de Janeiro 26, 1-83. Available at: http://www.sidra.ibge.gov.br. Accessed on March, 2013.

Li Z, Zhang M, Wang Y, Fernando WGD (2008) Mycelial compatibility group and pathogenicity variation of Sclerotinia sclerotiorum populations in sunflower from China, Canada and England. Plant Pathology 7:131-139.

Malvárez G, Carbone I, Grunwald NJ, Subbarao KV, Schafer M, Kohn LM (2007) New populations of Sclerotinia sclerotiorum from lettuce in California and peas and lentils in Washington. Phytopathology 97:470-483.

Mert-Turk F, Ipek M, Mermer D, Nicholson P (2007) Microsatellite and morphological markers reveal genetic variation within a population of Sclerotinia sclerotiorum from oilseed rape in the Çanakkale province of Turkey. Journal of Phytopathology 155: $182-187$.

Morrall RAA, Duczek J, Shear JW (1972) Variations and correlations within and between morphology, pathogenicity, and pectolytic enzyme activity in Sclerotinia from Saskatchewan. Canadian Journal of Botany 50:767-786.

Paula Júnior TJ, Vieira RF, Lobo Júnior M, Morandi MAB, Carneiro JES, Zambolim L (2006) Manejo integrado do mofobranco do feijoeiro. Viçosa MG. EPAMIG. 48p.

R Development Core Team. R: A language and environment for statistical computing. R. Foundation for Statistical Computing. Available at: http://www.R-project.org. Accessed on July, 2014.

Sanogo S, Puppala N (2007) Characterization of a darkly pigmented mycelial isolate of Sclerotinia sclerotiorum on Valencia peanut in New Mexico. Plant Disease 91:1077- 1082. 
Sexton AC, Howlett BJ (2004) Microsatellite markers reveal genetic differentiation among populations of Sclerotinia sclerotiorum from Australian canola fields. Current Genetics 46:357-365.

Sexton AC, Whitten AR, Howlett BJ (2006) Population structure of Sclerotinia sclerotiorum in an Australian canola field at flowering and stem-infection stages of the disease cycle. Genome 49:1408-15.

Sokal RR, Michener CD (1958) A statistical method for evaluating systematic relationship. University of Kansas, Science Bulletin 38:1409-1438.
Vleugels T, Baert J, Bockstaele EV (2013) Morphological and pathogenic characterization of genetically diverse Sclerotinia isolates from European red clover crops (Trifolium pratense L.). Journal of Phytopathology 161:254-262.

Vieira RF, Paula Júnior TJ, Teixeira H, Carneiro JES (2010) White mold management in common bean by increasing within-row distance between plants. Plant Disease 94:361-367.

Willetts HJ, Wong JA (1980) The biology of Sclerotinia sclerotiorum, $S$. trifoliorum, and $S$. minor with emphasis on specific nomenclature. The Botanical Review 46:101-165.

TPP-2014-0038

Submitted: 13 March 2014

Revisions requested: 7 July 2014

Accepted: 16 July 2014

Section Editor: Adalberto C. Café Filho 